\title{
NON-FINANCIAL INDICATORS FOR EVALUATION OF BUSINESS ACTIVITY
}

\author{
Inta Kotane, Irina Kuzmina-Merlino \\ Riga International School of Economics and Business Administration
}

\begin{abstract}
It is well-known that financial reports are the main source of information about company performance, and basing on them the business activities and financial position of a company are evaluated. However, under conditions of contemporary economic development company management cannot rely only on the evaluation system of financial indicators in order to manage the company successfully. The main indicators of business activity are not found only in financial data. Such indicators as quality, clients' satisfaction, innovations, market share quite often reveal the economic position of a company and opportunities for growth better than the financial indicators of company performance reflected in reports.

The balanced scorecard indicators, which include the financial perspective, clients' perspective, internal processes perspective and innovations and learning perspective, can be considered as the origin of non-financial indicators. The balanced scorecard indicators developed strategy maps were designed to trace and develop cause-effect links between long-term aims and implemented short-term activities. Initially the growth and learning perspective of the balanced scorecard indicators included employees' skills, opportunities of the information system, and such behavioral factors as motivation and powers; however, some changes were introduced into the balanced scorecard indicators and the growth and learning perspective is characterized now as intangible assets which are divided into three groups: human capital, information capital and organizational capital. Researches prove that the results of non-financial activity positively influence the results of financial activity and an increasing number of company managers transform the evaluation system of their company performance to trace non-financial evaluation indicators and thus use their new strategies in competition.

Despite the fact that in scientific literature the number of publication on this topic increases, researchers have not come to agreement about the content and structure of non-financial indicators as well as about the methods for their measurement and evaluation. The article reveals various theoretical approaches to understanding the nature, classification and measurement on non-financial indicators, which are in scientific literature, are considered as the indicators for measurement and evaluation of intellectual capital.

The aim of the paper is to provide recommendations on the development of non-financial indicators system and its practical implementation in Latvian companies on the basis of the study, analysis and generalization of the scientific economic publications in the field of company performance.

The research is based on the analysis and evaluation of special literature and scientific publications on the nonfinancial indicators of business activity and their role in the evaluation of company performance. General logical analysis and synthesis methods as well as content analysis and monographic analysis are used in the research.

The article is focused on the analysis and evaluation of previous researches on the non-financial indicators of business activity, overview and systematization of non-financial indicators used in the evaluation of business activity, including small enterprises performance.
\end{abstract}

Keywords: non-financial indicators, balanced scorecard indicators, evaluation, business activity.

\section{Introduction}

In order to ensure long-term activity, increase competitiveness and attract investments it becomes topical for many companies in Latvia to create a system for evaluating non-financial performance indicators.

Traditional methods for evaluation of business activity are based on the calculations of financial indicators and their evaluation and do not indentify all factors influencing company development. The analysis of company performance basing just on financial indicators provide incomplete evaluation of company performance as the internal, usually immeasurable factors of the company describing company's internal potential and future perspectives are not taken into consideration.
Despite the great number of theoretical publication on the problems of evaluating company performance, basing on the system of financial and non-financial indicators (Hafeez, 2002; Philips, Louvieris 2005; Craig, Moores, 2005; Lau, Sholihin, 2005; Fernandes et.al., 2006; Prieto, Revila, 2006; Wier et.al., 2007; Chen et.al., 2009; Cardinaels, van VeenDirks, 2010) there are problems in practical application of this indicators' system as there is no single approach to identification, classification, measurement and evaluation of non-financial performance indicators.

The topic of the paper is not sufficiently researched in Latvia, thus, the authors of the article have analyzed and evaluated researches done abroad about non-financial indicators of business activity and have assessed the classifications of non-financial indicators. 
The aim of the paper is to make recommendations on the development of non-financial indicators system and its practical implementation for Latvian companies on the basis of study, analysis and generalization of the scientific economic publications in the field of company performance.

The present article has the following tasks:

- To investigate the essence of non-financial indicators and show their role in company activity performance;

- To study and systematize possible approaches to designing content and structure of non-financial indicators as an essential part of company's intellectual capital;

- To analyze the advantages and disadvantages of nonfinancial indicators;

- To develop recommendations for practical implementation of non-financial indicators to evaluate company's business activity.

The research is based on the analysis and evaluation of special literature and scientific publications about nonfinancial indicators of business activity and their role in evaluation of the company performance. General logical analysis and synthesis methods, content analysis and monographic analysis are used in the research.

\section{Non-financial indicators and balanced scorecard system}

Kaplan and Norton (Harvard Business Review, 2008) have created a balanced scorecard (BSC), which includes financial and non-financial indicators providing information about the results of completed activities. Financial indicators are supplemented by three kinds of evaluating performance related to the clients' satisfaction, internal processes in a company and its ability to learn and develop. BSC lets managers to have a look at their business from four important perspectives and answer four important questions:

- How clients see us (clients' perspective);

- Where we need to develop (internal perspective);

- If we can improve and create a value (innovations and learning perspective);

- How our shareholders see us (financial perspective).

BSC method is widely used to evaluate company's performance around the world. For example, in England there are analyzed options using BSC to evaluate small and medium-sized enterprises performance (Sousa et.al.,2006), to organize manufacturing companies performance (Fernandes et.al.,2006), to evaluate hotel industry companies performance (Philips, Louvieris, 2005), to have strategic plans in family companies (Craig, Moores, 2005).

Taking into consideration the aim of the research, the authors of the article will analyze the non-financial indicators included in the balanced indicators system in their further research.

Kaplan and Norton (Harvard Business Review, 2008) assert that non-financial performance measures are better indicators for future financial performance than lagged financial measures. Wiersma's opinion is that non-financial indicators have more information content than financial indicators. This claim is based on the observation that financial indicators only partially reflect the impact of current managerial actions. Financial indicators omit the impact of actions taken today; it takes some time before they accumulate in improved financial performance. Non- financial indicators are expected to record the impact of these actions earlier, because they more directly track the impact of actions taken (Wiersma, 2006)

According to the researcher Hogue measurement of nonfinancial indicators includes three aspects: (1) customer; (2) internal business processes; and (3) learning and growth. The customer perspective includes: market share; customer

Table 1. Key non-financial performance indicators (designed by the authors)

\begin{tabular}{|c|c|c|c|}
\hline & $\begin{array}{l}\text { Manufacturing } \\
\text { (Fernandes et.al., 2006) }\end{array}$ & $\begin{array}{l}\text { Hotel sector } \\
\text { (Philips, Louvieris, 2005) }\end{array}$ & $\begin{array}{l}\text { Family companies } \\
\text { (Craig, Moores, 2005). }\end{array}$ \\
\hline $\begin{array}{l}\text { Customer/ } \\
\text { Customer related }\end{array}$ & $\begin{array}{l}\% \text { of sales from new } \\
\text { products } \\
\text { On-time delivery } \\
\text { Share of key accounts } \\
\text { No. of cooperative } \\
\text { efforts }\end{array}$ & $\begin{array}{l}\text { Guest surveys } \\
\text { Mystery guest } \\
\text { Participation in grading schemes } \\
\text { Anecdotal feedback via staff } \\
\text { Customer satisfaction levels } \\
\text { Average spend } \\
\text { Customer satisfaction levels } \\
\text { Customer retention rate }\end{array}$ & $\begin{array}{l}\text { Operational excellence } \\
\text { Customer intimacy } \\
\text { Product leadership }\end{array}$ \\
\hline $\begin{array}{l}\text { Internal } \\
\text { Processes/ } \\
\text { Internal business }\end{array}$ & $\begin{array}{l}\text { Cycle time } \\
\text { Efficiency } \\
\text { Actual launch vs. delay } \\
\text { Reduction in W/F }\end{array}$ & $\begin{array}{l}\text { Meeting financial targets } \\
\text { Internal auditing } \\
\text { Completion of capital projects } \\
\text { Staff satisfaction surveys } \\
\text { Staff development reviews } \\
\text { Staff retention rate percentage } \\
\text { Wages (\%) to achieve turnover } \\
\text { Staff incentive schemes (performance-related pay) }\end{array}$ & $\begin{array}{l}\text { Spurring innovation } \\
\text { Increasing customer value } \\
\text { Achieving operational } \\
\text { excellence } \\
\text { Promoting corporate } \\
\text { citizenship }\end{array}$ \\
\hline $\begin{array}{l}\text { Learning } \\
\text { and Growth / } \\
\text { Innovation / } \\
\text { learning }\end{array}$ & $\begin{array}{l}\text { Time to new process } \\
\text { maturity } \\
\% \text { of product } \\
\text { representing } 80 \% \text { sales } \\
\text { Compare to competitors }\end{array}$ & $\begin{array}{l}\text { Number of new products/services } \\
\text { Process improvement initiatives } \\
\text { Networking relationships } \\
\text { Membership of trade/professional bodies } \\
\text { Participation in grading schemes } \\
\text { Courses completed by staff } \\
\text { Level of multiskilling } \\
\text { Productivity }\end{array}$ & $\begin{array}{l}\text { Employee capabilities and } \\
\text { skills } \\
\text { Technology } \\
\text { Corporate climate }\end{array}$ \\
\hline
\end{tabular}


satisfaction survey; on time delivery; customer response time and warranty repair cost. The second aspect "the internal business processes" is characterized as a material and labour efficiency variance; process improvement and reengineering; new product introduction; and long-tern relations with suppliers. The last "learning and growth perspective" includes: staff development and training; workplace relations; employee satisfaction; and employee health and safety (Hoque, 2005).

In Table 1 there are summarized non-financial performance indicators applying BSC in manufacturing, hotel industry and family companies. The data in the table prove that companies use different indicators within BIS. These indicators are grouped in three perspectives using BIS approach: customer-related, internal business processes, learning and growth.

Kaplan and Norton (Harvard Business Review, 2008) consider that BSC is not a pattern to be applied to business in general or even within one industry. A different market situation, various product strategies and competition conditions require diverse systems of balanced indicators. In order to evaluate companies performance there are created adjusted BSC complying with the mission, strategy, technology and culture of a specific company. BSC provides managers information from four various perspectives, reduces cluttering of information by limiting it to a certain number of applied indicators.

Craig and Moores (Craig, Moores, 2005) describe perspectives using BSC method not only for a family company, but also for a family as primary social group. There have been named the main customer-related indicators: awareness of the family name, use of family in marketing initiatives, quality that reflects family brand. There have been named the following internal processes: investment in technology that will benefit future generations, professional work practices that will attract best family and non-family employees, philanthropic activities. The last group of indicators related to learning and growth includes: creating career paths for family members, making involvement in the business a privilege, encouraging and providing seed funding for new ventures presented by family members.

Within the framework of BSC method non-financial indicators have specific measurements or aims to be achieved which are compared by the authors to the actual measurements of these indicators (for example, Cardinaels, van Veen-Dirks, 2010; Coram et.al., 2011). Table 2 provides comparison of non-financial performance indicators, which are divided into three groups (customer-related, internal business processes, learning and growth). Among non-the financial performance indicators described by the authors there shall be marked common or identical indicators, for example, customers' satisfaction, and slightly different indicators, for example, hours of employee training/ sales training per employee as well as different indicators.

Non-financial indicators refer to the following business functions: manufacturing (product quality, relations with suppliers, delivery and services), sales and marketing, human resources, research and development, environment (workplace environment and surrounding environment) (Shaw, 1999).

Non-financial performance indicators are not divided into three perspectives of BSC as it is shown in Tables 1 and 2. In its turn, Table 3 displays non-financial performance indicators not distinguishing customer-related, internal business processes and learning and growth indicators.

Table 2. Non-financial performance indicators 2 (designed by the authors)

\begin{tabular}{|l|l|}
\hline \multicolumn{1}{|c|}{$\begin{array}{c}\text { (Cardinaels, van Veen-Dirks, } \\
\text { 2010) }\end{array}$} & \multicolumn{1}{|c|}{ (Coram et.al.,2011) } \\
\hline \multicolumn{2}{|c|}{ Customer-related } \\
\hline $\begin{array}{l}\text { Customer satisfaction rating } \\
\text { Repeat sales }\end{array}$ \\
\hline $\begin{array}{l}\text { Sales per square foot of retail } \\
\text { space } \\
\text { New items first to market }\end{array}$ & $\begin{array}{l}\text { Returns by customers (\% } \\
\text { of sales) }\end{array}$ \\
\hline \multicolumn{2}{|c|}{ Internal business processes } \\
\hline $\begin{array}{l}\text { Returns to suppliers (\%) } \\
\text { Average markdowns (\%) }\end{array}$ \\
\hline $\begin{array}{l}\text { Orders filled within one week } \\
\text { Stock-outs }\end{array}$ & $\begin{array}{l}\text { Sales from Trailblazer's } \\
\text { brand }\end{array}$ \\
\hline \multicolumn{2}{|c|}{ Learning and growth } \\
\hline Suggestions per employee & $\begin{array}{l}\text { Hours of employee } \\
\text { Training per employee }\end{array}$ \\
\hline $\begin{array}{l}\text { Hours of sales training per } \\
\text { employee }\end{array}$ & $\begin{array}{l}\text { Average tenure of sales } \\
\text { personnel (years) }\end{array}$ \\
\hline $\begin{array}{l}\text { Retail experience of sales } \\
\text { managers }\end{array}$ & \\
\hline Employee satisfaction (\%) &
\end{tabular}

Non-financial performance indicators have a long-term aim emphasizing the role of increasing customer loyalty, attraction of new customers, improvement of perceived company image and reputation (Chen et.al.,2009). Non-financial performance has no significant value for company managers; however, it can be used as a determining financial performance indicator and especially as a future financial performance indicator, which is not reflected in the current accounting indicators (Prieto, Revila, 2006). Clients' satisfaction can be described as an increasing clients' wish to purchase new items or repurchase. Satisfied clients buy more frequently and in larger quantities as well as purchase other goods and use other services offered by the company. Besides, consistently offering goods and services, which satisfy clients, company's financial performance improves as failure-related costs reduce. The more clients, the higher profit a company gains. (Prieto, Revila, 2006; AbdelMaksoud et.al., 2005) (see Table 3).

Table 3. Non-financial performance indicators 3 (designed by the authors)

\begin{tabular}{|c|c|c|}
\hline $\begin{array}{c}\text { (Chen et.al., } \\
\text { 2009). }\end{array}$ & $\begin{array}{c}\text { (Prieto, Revila, } \\
\text { 2006) }\end{array}$ & $\begin{array}{c}\text { (Abdel-Maksoud } \\
\text { et.al, 2005) }\end{array}$ \\
\hline $\begin{array}{l}\text { - } \text { Customer } \\
\text { loyalty } \\
\text { - Attracting } \\
\text { new } \\
\text { customers } \\
\text { - Competitive } \\
\text { advantage } \\
\text { - Reputation } \\
\text { - Perceived } \\
\text { image }\end{array}$ & $\begin{array}{l}\text { - Customers' } \\
\text { satisfaction } \\
\text { - Growth of } \\
\text { number of } \\
\text { customers } \\
\text { - Quality in } \\
\text { products and } \\
\text { services } \\
\text { - Employee } \\
\text { satisfaction } \\
\text { - Organizational } \\
\text { reputation }\end{array}$ & $\begin{array}{l}\text { - Customers' } \\
\text { satisfaction } \\
\text { - On-time delivery } \\
\text { - Efficiency and } \\
\text { utilisation } \\
\text { - Product quality } \\
\text { - Employee morale } \\
\text { (staff turnover, } \\
\text { lateness, } \\
\text { absenteeism) }\end{array}$ \\
\hline
\end{tabular}


Clients' loyalty can be described as clients' trust to a certain company, product or service. Under contemporary competitive conditions companies have to solve an ongoing problem: how to keep and strengthen their position in the market and at the same time maintain efficiency. Clients' loyalty can be described as one of the key factors for success in business.

Employees' satisfaction or morale is reflected in company's income, labor efficiency and productivity improve (Prieto, Revila, 2006; Abdel-Maksoud et.al, 2005).

A company having good reputation needs lower costs to attract new customers or employees. Good reputation can also help introduce new goods and services by reducing customer trial risk. Reputation can also benefit by establishing and maintaining relations with key suppliers, distributors and potential partners (Prieto, Revila, 2006).

Summarizing this part of the article it can be concluded that all authors consider non-financial indicators systems as a component of BIS; however, each author has his own perception of the non-financial indicators system.

\section{Non-financial indicators as an essential part of intellectual capital}

Non-financial indicators mentioned above, which measure the results of a certain kind of business activity, are invisible resources contributing to the company value. In economic literature such invisible resources are called "intangible assets", but in scientific literature - "intellectual capital".

The authors of the paper pay attention to the existing problems of the measuring non-financial indicators; the reason for which, in most cases, is the impossibility to apply quantitative methods to measure intellectual capital.

Classification of non-financial indicators lies on the basis of the model of its measurement (Kuzmina, 2008). Every measurement model is based on certain combinations of indicators, and therefore is unique. Scorecard method developing by Kaplan and Norton is one of them.

According to Kaplan and Norton (Harvard Business Review, 2008) BSC has 4 perspectives: financial perspective, client perspective, internal business processes perspective and innovation and learning perspective. BSC is strategy and vision oriented, not control oriented. It puts forward aims, but assumes that staff will adapt its behavior and take actions to reach them. Indicators are introduced to guide staff to a common vision.

Further development of BSC methodology is characterized by BIS as a basis for a new system of strategic management. Kaplan and Norton have developed a map of strategies which let establish cause-effect links between long-term aims (strategic management) and performance indicators (shortterm activities) (Духонин Е.Ю. и др., 2005).

Analyzing further the opinions of researchers about the nature of intellectual capital it can be concluded that in each case the definition of intellectual capital included a definite set of non-financial indicators, which are grouped in three areas or strategic perspectives.

For example, Webster M. considers intellectual capital to be a component of intangible assets. In his opinion, intangible assets include intellectual capital (patents, licenses, etc.) and other intellectual property (human capital - knowledge, loyalty to organization, motivation, etc..; client capital - clients' loyalty, distribution channels, etc.; organization (infrastructure) - information systems, management philosophy, corporate culture, etc.) (Webster M. et.al. 2004).

Kim Dong-Young and Kumar V. consider that intellectual capital includes three parts: human capital, structural capital and relations capital. In his opinion, the indicators characterizing human capital are employees' satisfaction, number of training hours and training costs per employee, etc. Structural capital is characterized by such indicators as the number of patents, corporate culture, staff ethics, etc., but relations capital has such indicators as clients' satisfaction, clients' loyalty, brand value, etc. (Kim Dong-Young, Kumar V., 2009).

Ballow J.J. (Ballow J.J. et.al., 2004) thinks that intellectual capital is composed of three parts: relations capital, organization capital and human capital. The authors have marked clients' loyalty, quality of offered contracts, etc. as the indicators characterizing relations capital. In authors' opinion, organization capital has the following indicators reputation, structural opportunities, etc., but human capital is described by such indicators as staff loyalty, employees' reputation, etc.

We can see non-financial performance indicators among the indicators characterizing intellectual capital (see Tables 1, 2, 3), for example, clients' loyalty, employees' satisfaction, number of training hours per employee, etc.

Initially the learning and growth perspective included employees' skills, opportunities of information systems and such behavioral factors as motivation and powers (Henhall R.H., Langfield-Smith K , 2007), but within the recent approach of BIS the learning and growth perspective is described as intangible assets having three parts: human capital, information capital and organization capital (Kaplan R.S., Norton D.P., 2004).

There is a positive link between learning skills and nonfinancial performance indicators as well as non-financial performance results and financial performance results. Companies taking care of their clients, employees and society in general can reach better financial performance indicators. Improvement of non-financial performance indicators does not have immediate positive impact on financial performance indicators. Managers must understand that satisfied clients and shareholders will automatically increase company profit. In general, a long-term perspective is needed to measure the training effect and business activity results (Prieto, Revila, 2006).

The learning process as one of the non-financial indicators is considered to be an element of the knowledge-based management process. As a result of training employees gain knowledge and master skills, as well as change their attitude, behavior and motivation. The result of the complex system is the result of business activity, which is divided into two groups: financial indicators (ROI, ROA, ROE, ROS, turnover, productivity) and non-financial indicators (staff turnover, shortage, conflicts, product quality, services and innovations). The company's strategic role and impact on the learning process and results of business activity are noted (Thang et. al., 2010). Qualitative analysis, which includes analysis of financial indicators (analysis of financial reports, ROI, net present value, etc.) and non-financial indicators (staff training, communication practice, assessment of product and process 
knowledge, assessment of individual, context, satisfaction and process knowledge) is one of the knowledge-based management measurement methods (Huang et.al., 2007).

Despite standardized calculations to measure the results of intangible assets performance, for example, impact of brands in the 1990s, the non-financial performance identification, measurement and reporting mechanism is not sufficiently developed. Much of this lack of standardization has to do with the present voluntary nature of such reporting. Those organizations that put themselves under the onus of nonfinancial performance metrics do so of their own free will, thus there is much variation from one organization to another as they formalize their respective reporting formats (KLM Inc., 2004).

The authors consider that companies have a great deal of flexibility in the treatment of non-financial indicators to complete the reports on intellectual capital as an additional part of the financial statement of a company. Reporting rules do not fully determine actual reporting practice.

Further research on business activity non-financial indicators shall be related to detailed study of intangible assets measurement and assessment methods and approaches, which are analyzed in scientific literature in relation to intellectual capital.

\section{Advantages and disadvantages of non-financial performance indicators}

In the previous part of the paper it has been noted that in practice there are certain problems in measurement and assessment of non-financial indicators. Thus, business performance assessment basing on non-financial indicators has both advantages and disadvantages. More profound research was conducted by Ittner and Larcker (2000), who described the advantages and disadvantages on nonfinancial performance indicators in comparison to financial performance indicators; later in 2003 they completed their analysis by identifying company errors in measurement of non-financial performance and options for improving nonfinancial performance measurement. Within the paper the authors schematically summarized the opinions of Ittner and Larcker as displayed in Figure 1 and analyzed the opinions of the researchers.

The main advantages of non-financial performance indicators seen in Figure 1 can be described as the advantages of BSC method (closer link to company's long-term strategies, better displayed future financial performance results, indirect, quantitative indicators of intangible assets), as the aim the map of strategies and BSC is identifying and developing causeeffect links within the strategy implemented by a company.

Analyzing the disadvantages of non-financial performance indicators, the authors of the article have concluded that measurement and assessment of non-financial performance indicators are complicated by the time and cost factor, which can be described as the need for extra time to explain employees the principles and advantages of using a non-financial performance system as well as calculation and introduction of non-financial indicators require additional information. It is complicated to measure and compare non-financial performance indicators because it is difficult to measure the results of company performance or arrive to compromise between indicators if some indicators are expressed in time units, but others in quantitative units or percentage, or even in a free form. As a result, a variety of non-financial indicators measurement methods can lead to imprecise or even erroneous measurement of company's non-financial performance. BSC method determines identifying causal links in a company, but in case of unknown or unrecognized causal links a company may concentrate attention to wrong aims, thus complicating decision making by company managers.

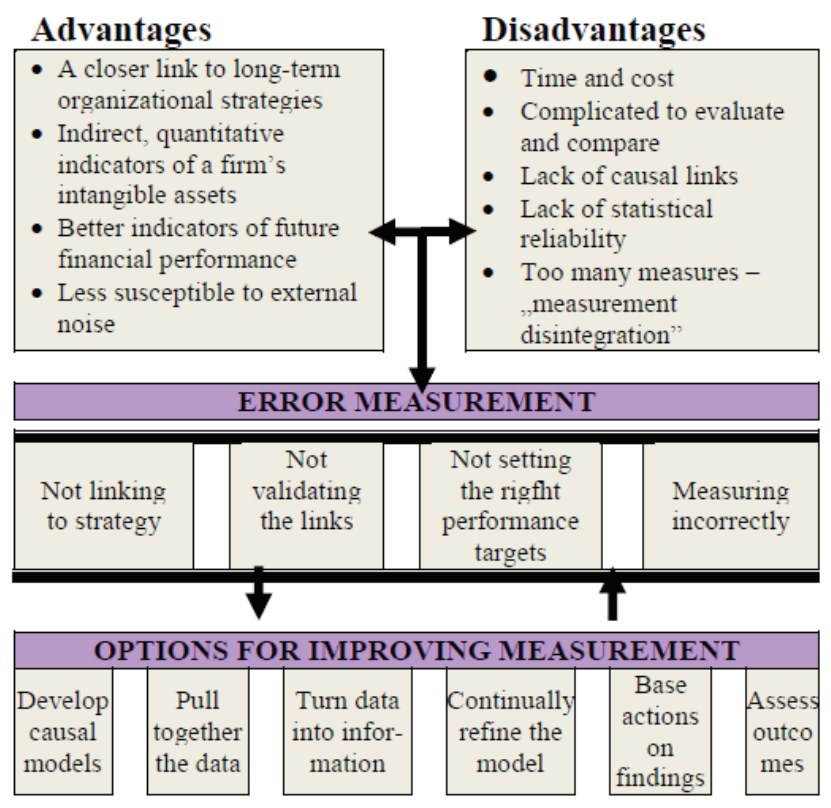

Figure 1. Advantages and disadvantages of nonfinancial performance indicators, companies' errors in their measurement and improvement of measurement errors (created by the authors based on the data of Ittner and Larcker)

Ittner and Larcker (2000) consider that non-financial performance indicators lack statistical reliability because many non-financial data, for example, satisfaction indicators, are based on surveys having a certain number of respondents and quite few questions.

Ittner and Larcker (2003) are aware of companies' errors in measurement of non-financial performance resulting from identification and assessment of company's non-financial indicators advantages and disadvantages. BSC method, for example, does not determine which fields provide the greatest contribution to the company's financial results. Successful companies use causal models identifying causal links between the implemented measures and performance results. The companies using causal models can rarely actual improvement in non-financial performance measurement and its impact on future financial performance results. Besides, the researches of Ittner and Larcker (2003) prove that $70 \%$ of companies use indicators which are not sufficiently statistically grounded and reliable.

Options for improvement of non-financial indicators (see Figure 1) are based on the application of a causal model, continuous improvement of the model, use model data in making decisions, and assessment of model performance outcomes. In order to introduce a causal model successfully it is needed to summarize information and check causal links within the model by applying mathematical statistics and other methods (for example, target group method, interview method). 
The authors consider that companies, including Latvian companies, can gain opportunities to identify better company performance results and measure the company's market value by applying the causal model and BSC and taking into consideration the potions for improvement of non-financial indicators offered by Ittner and Larcker (2003).

\section{Conclusions}

- Non-financial indicators reflect individual elements of company's intellectual capital; they are intangible resources comprising the company's value.

- In scientific literature there is no common approach to the classification, measurement and assessment methods of non-financial indicators. As there are no common ways to reveal information, it causes difficulties in displaying information in relation to nonfinancial indicators.

- The most widespread method for identifying, measuring and displaying non-financial performance indicators is the a balanced scorecard system, which includes financial perspective, clients perspective, internal business processes perspective and innovations and learning perspective. The balanced scorecard system developed, strategy-mapping was elaborated to trace and develop causal links between long-term aims and implemented short-term activities.

- Despite the fact that standardized calculations have appeared to measure intangible assets performance results, for example, impact of brands in the 1990s, the non-financial performance identification, measurement and reporting mechanism is insufficiently elaborated.

- Assessment of company's non-financial performance errors basing on the recognition and assessment of non-financial indicators advantages and disadvantages provides an opportunity to consider options for improvement of non-financial indicators measurement.

On the basic of the above conclusions, it is possible to make the following recommendations for the practical implementation of non-financial indicators for evaluation of company's business activity:

- Description of a company's strategy;

- Identifying the subject of non-financial indicators for management purposes, because the classification of indicators defines the basis of the model of its measurement;

- Selecting the appropriate method of value; Kaplan and Norton's strategy-mapping approach could be useful for Latvian companies;

- Developing a report on intellectual capital as an additional part of a company's financial statement. Performance can be monitored year by year, or can be compared to other similar organizations. A report on intellectual capital is considered to be a tool for financial and non-financial indicators measurement, management and enhancement of company's attractiveness for investors.

- Despite the fact that scientific interest in the problem of implementation of non-financial indicators is constantly growing, the above presented theme is still being the subject of scientific discussions and disputes.

\section{References}

Abdel-Maksoud A., Dugdale D., Luther R Non-financial performance measurement in manufacturing companies. // The British Accounting Review, 2005, Vol.37, P.261297.

Andriessen. D. Making Sense of Intellectual Capital: Designing a Method for the Valuation of Intangibles. Butterworth-Heinemann is an imprint of Elsevier, 2004.

Ballow J.J., Burgman R., Molnar M.J. Managing for shareholder value: intangibles, future value and investment decisions.// Journal of Business Strategy, 2004, Vol. 25 Iss: 3, P.26 - 34

Cardinaels E., van Veen-Dirks P.M.G. Financial versus non-financial information: The impact of information organization and presentation in a Balanced Scorecard. // Accounting, Organizations and Society, 2010, Vol.35, P.565-578.

Chen Ja-Shen, Tsou Hung Tai, Huang A.Ya-Hui. Service Delivery Innovation: Antecedents and Impact on Firm Performance. // Journal of Service Research, 2009, Vol.12, Number 1, P.36-55.

Coram P.J., Mock T.J., Monroe G.S. Financial analysts' evaluation of enhanced disclosure of non-financial performance indicators, The British Accounting Review, 2011, doi:10.1016/j.bar.2011.02.001

Craig J., Moores K. Balanced Scorecards to drive the strategic planning of family firms. // Family business review, 2005, Vol. XVIII, No.2, P.105-122.

Fernandes K.J., Raja V., Whalley A. Lessons from implementing the balanced scorecard in a small and medium size manufacturing organization.// Technovation. 2006, Vol.26, P. 623-634.

Hafeez K., Zhang YB., Malak N. Determining key capabilities of a firm using analytic hierarchy process. // Int. J. Production Economics, 2002, Vol.76, P.39-51.

Harvard Business Review on Measuring Corporate Performance (Uzn̄ēmuma darbības novērtēšana: rakstu apkop./ no angḷu val.) - Rīga: Lietišķās informācijas dienests, 2008. - 179 lpp. ISBN 9789984826271

Henhall R.H., Langfield-Smith K. Multiple Perspectives of Performance Measures.// European Management Journal, 2007, Vol. 25, No. 4, P.266-282.

Hoque Z. Linking environmental uncertainty to non-financial performance measures and performance: a research note. // The British Accounting Review, 2007, Vol.37, P.471-481.

Huang Mu-Jung, Chen Mu-Yen, Yieh K. Comparing with your main competitor: the single most important tasks of knowledge management performance measurement. // Journal of Information Science, 2007, Vol. 33(4), P.416434.

Ittner C., Larcker D. Non-financial Performance Measures: What Works and What Doesn't, 2000. Online paper: http://knowledge.wharton.upenn.edu/article. $\underline{\text { cfm? articleid }=279}$

Ittner C.D., Larcker D.F. Coming up short on nonfinancial performance measurement. // Harvard Business Review, 2003. 
Kaplan R.S. and Norton D.P. Strategy Maps - Converting intangible assets into tangible outcomes. 2004, Harvard Business School Press, Boston. Online paper: http:// www.sas.com/solutions/spm/StrategyMaps.pdf

Kim Dong-Young, Kumar V. A framework for prioritization of intellectual capital indicators in R\&D.// Journal of Intellectual Capital, 2009, Vol. 10 Iss: 2, P.277 - 293.

KLM, Inc. Non-financial performance measurements. 2004. Online paper: http://www.klminc.com/intellect_cap/nonfinancial.html

Kuzmina I. Accounting for Intangible Assets in the Context of a Company Strategy. In: Accounting and Finance in Transition. Greenwich University Press, London, 2008. Pages 209-229.

Lau C.H., Sholihin M. Financial and non-financial performance measures: How do they affect job satisfaction? The British Accounting Reviewer, 2005, Vol. 37, P.389-413.

Philips P., Louvieris P. Performance measurement systems in tourism, hospitality and leisure small medium-sized enterprises: a balanced scorecard perspective.// Journal of Travel Research, 2005, Vol.44, P.201-211.

Prieto I.M., Revilla E. Learning capability and business performance: a non-financial and financial assessment // Learning Organization, 2006, Vol.13 Iss: 2, P.166 - 185.

Shaw A. A Guide to Performance Measurement and NonFinancial Indicators. Online paper: http://www.fpm.com/ journal/mattison.htm
Sousa S.D., Aspinwall E.M., Rodrigues A.G. Performance measures in English small and medium enterprises: survey results.// Benchmarking: An International Journal, 2006, Vol.13 No. 1/2, P.120-134

Thang, N. N., Quang, T. \& Buyens, D. The Relationship between Training and Firm Performance: A Literature Review, Research and Practice in Human Resource Management, 2010. 18(1), 28-45. On line paper: http:// rphrm.curtin.edu.au/2010/issue1/training.htm

Webster M. and Sugden D.M., Tayles M.E. The measurement of manufacturing virtuality.// International Journal of Operations \& Production Management, 2004, Vol. 24 Iss: 7, P.21 - 742.

Wier B., Hunton J., Hassab Elnaby H.R. Enterprise resource planning systems and non-financial performance incentives: The joint impact on corporate performance. // International Journal of Accounting Information Systems, 2007, Vol.8, P.165-190.

Wiersma E. An exploratory study of relative and incremental information content of two non-financial performance measures: Field study evidence on absence frequency and on-time delivery. // Accounting, Organizations and Society, 2008, Vol.33, P.249-265.

Духонин Е.Ю. и др. Управление эффективностью бизнеса. Концепция Business Performance Management. - М.: Альпина Бизнес Букс, 2005, стр 269.

The article has been reviewed.

Received in April, 2011; accepted in June, 2011. 